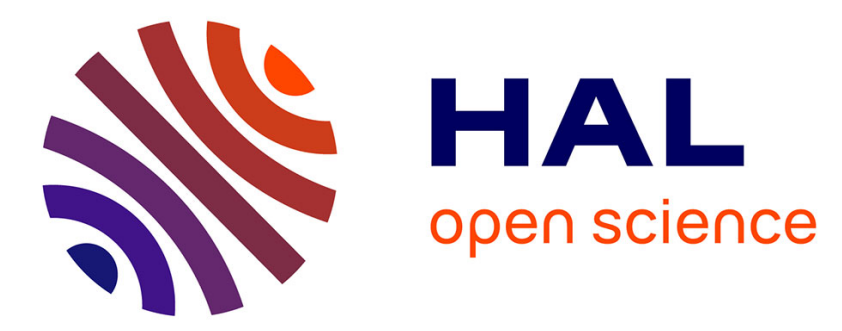

\title{
Performance and Exhaust Emissions of a Diesel Engine Fuelled with Croton Megalocarpus (Musine) Methyl
} Ester

\author{
B. Aliyu, D. Shitanda, S. Walker, B. Agnew, S. Masheiti, R. Atan
}

\section{- To cite this version:}

B. Aliyu, D. Shitanda, S. Walker, B. Agnew, S. Masheiti, et al.. Performance and Exhaust Emissions of a Diesel Engine Fuelled with Croton Megalocarpus (Musine) Methyl Ester. Applied Thermal Engineering, 2010, 31 (1), pp.36. 10.1016/j.applthermaleng.2010.07.034 . hal-00685794

\section{HAL Id: hal-00685794 https://hal.science/hal-00685794}

Submitted on 6 Apr 2012

HAL is a multi-disciplinary open access archive for the deposit and dissemination of scientific research documents, whether they are published or not. The documents may come from teaching and research institutions in France or abroad, or from public or private research centers.
L'archive ouverte pluridisciplinaire HAL, est destinée au dépôt et à la diffusion de documents scientifiques de niveau recherche, publiés ou non, émanant des établissements d'enseignement et de recherche français ou étrangers, des laboratoires publics ou privés. 


\section{Accepted Manuscript}

Title: Performance and Exhaust Emissions of a Diesel Engine Fuelled with Croton Megalocarpus (Musine) Methyl Ester

Authors: B. Aliyu, D. Shitanda, S. Walker, B. Agnew, S. Masheiti, R. Atan

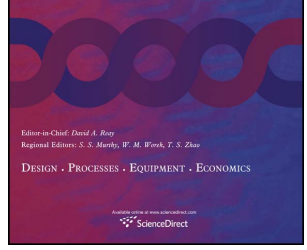

PII:

$$
\text { S1359-4311(10)00319-4 }
$$

DOI:

10.1016/j.applthermaleng.2010.07.034

Reference: $\quad$ ATE 3195

To appear in: Applied Thermal Engineering

Received Date: 19 May 2010

Revised Date: 26 July 2010

Accepted Date: 31 July 2010

Please cite this article as: B. Aliyu, D. Shitanda, S. Walker, B. Agnew, S. Masheiti, R. Atan. Performance and Exhaust Emissions of a Diesel Engine Fuelled with Croton Megalocarpus (Musine) Methyl Ester, Applied Thermal Engineering (2010), doi: 10.1016/j.applthermaleng.2010.07.034

This is a PDF file of an unedited manuscript that has been accepted for publication. As a service to our customers we are providing this early version of the manuscript. The manuscript will undergo copyediting, typesetting, and review of the resulting proof before it is published in its final form. Please note that during the production process errors may be discovered which could affect the content, and all legal disclaimers that apply to the journal pertain. 


\title{
Performance and Exhaust Emissions of a Diesel Engine Fuelled with Croton Megalocarpus (Musine) Methyl Ester.
}

\author{
B. Aliyu,
}

Department of Agricultural Engineering, Federal University of Technology, Yola, Nigeria

D. Shitanda,

Biomechanical and Environmental Engineering Department, Jomo Kenyata University of Agriculture and Technology, Nairobi, Kenya.

S Walker, B. Agnew*,

School of the Built Environment, Northumbria University, Newcastle upon Tyne, UK. S. Masheiti,

School of Mechanical and Systems Engineering, Newcastle University, Newcastle upon Tyne, UK.

$$
\text { R. Atan, }
$$

Faculty of Mechanical Engineering, Universiti Teknologi Mara, Shah Alam, Malaysis.

Key Words: Croton Megalocarpus, Musine, Bio-fuel, Methyl Ester, Engine test.

* Author for correspondence, brian.agnew @ northumbria.ac.uk; 0044 (0)191 2273779

\begin{abstract}
The performance of a 4 stroke 3 cylinder direct injection naturally aspirated, Perkins D3.142 engine was measured in order to determine the suitability of a bio-fuel produced from the seeds of Croton Megalocarpus for engine use. The raw oil from the seeds was subjected to a transesterfication process and supplied to the engine as a croton methyl ester (CME) in various blends with diesel fuel. The engine performance (brake thermal efficiency, brake specific fuel consumption and exhaust temperature) were measured and evaluated. A Horiba PG-250 portable analyser was used to measure the $\mathrm{CO}, \mathrm{HC}, \mathrm{CO}_{2}$, $\mathrm{NO}_{\mathrm{x}}$, and $\mathrm{O}_{2}$, concentrations. The tests indicated a lower brake thermal efficiency for CME compared with the pure diesel fuel. The exhaust gas temperature increased with increase in load for all tested fuels. It was found that the performance of the CME was comparable to pure diesel fuel but the bio-diesel produced lower smoke and $\mathrm{NO}_{\mathrm{x}}$ emissions. Emissions of $\mathrm{CO}$ were reduced at higher loads with the bio-fuel. The performance of the engine indicated that $\mathrm{CME}$ has properties and characteristics that make it a viable additive or alternative to conventional fossil diesel fuel.
\end{abstract}

\subsection{Introduction:}

As global oil reserves decline and climate change resulting from the burning of fossil fuels becomes more apparent, it has become necessary to develop and exploit sustainable and non-polluting (i.e. carbon neutral) energy sources. At the same time it has been estimated that oil production will show a downward trend to become just $35 \%$ of today's production by the year 2075. It is therefore necessary to find alternative sources of renewable energy if present energy consumption (and living standards) is to be 
maintained. Of the possible renewable sources bio-fuels are the only viable choice for use in transport systems that do not require huge investment in infrastructure and vehicle design. But some biomass alternatives such as ethanol, methanol and bio-diesel derived from food crops such as palm oil and rape seed oil are not without their critics. The consumption of biodiesel in the USA alone in 2006 was of the order of 250 million US gallons, most of which was produced from food crops or was grown on land previously used for food or animal feed production. In Europe pump diesel now contains 5\% biofuel. In Indonesia large tracts of Equatorial forest are being destroyed to make way for palm oil production that is destroying the local ecosystem and it has been reported that the overall carbon signature of palm oil is actually greater than coal. There is now concern about moral and ethical issues associated with the substitution or use of food crops for bio fuel production [1]. The work reported in this paper examined a non food, environmentally friendly source of biodiesel, the Croton Megalocarpus Tree. Croton Megalocarpus is a tree from the family Eurhorbiaceae that grows generally in East Africa at an altitudinal range of 4,000-6,000 ft. The tree grows up to $15-35 \mathrm{~m}$ high [2], but can reach a height of $40 \mathrm{~m}$ or more [3], figure 1.

\section{Figure 1 A Croton Megalocarpus tree grown as an ornamental plant in Kenya}

The wood from the tree is of medium weight, hard, termite resistant and strong; it is used as a source of timber and fencing material. The leaves have high levels of nitrogen and phosphorous and serve as a source of mulch in plantations [4]. Each fruit contains 3 ellipsoid ovoid or oblong-ellipsoid seeds which have an oil content of $30 \%$ by mass and a large proportion of protein. The Croton tree can survive on marginal agricultural land, not suitable for food production and can be planted to resist desert encroachment. The high protein content of the seed husks make them a very suitable poultry feed. The oil from the seeds can be extracted by mechanical extraction methods (pressing) or by solvent/chemical extraction methods. Presses such as manual screw, stork hydraulic hand press, motor jack press, mechanical press and a combination of these presses are available. Solvent extraction is done after preparatory steps such as crushing, blending and milling. The solvent is then added into the resulting paste and stirred until well mixed. The resulting solution is then filtered and the solvent driven off and recovered by a process of distillation to leave the raw vegetable oil. The seeds used in this study were obtained from the Kenya Forestry Research Institute Seed Centre in Kenya. The oil was obtained by both mechanical and chemical extraction methods in Kenya and then transported to Newcastle to be subjected to transesterification to be converted to biodiesel. The composition of the resulting fuel was determined by examination in a mass spectrometer and a sample was sent to the Fuel Oil Bunker Analysis Services (FOBAS) for analysis to determine the ignition and combustion characteristics in a constant volume bomb test according to IP541/06. Other properties determined at FOBAS included the density (EN ISO 3675) the sulphur content (EN ISO 20846r), the viscosity (EN ISO 3104) and the ash content (EN ISO 3451). The Croton methyl ester contains predominantly Oleic acid ester, with lesser quantities of Linoleic, Linolenic and Palmitic esthers. The properties of CME compared to commercially available red diesel (RD) fuel 
(EN590-Directive 98/70/CE) and a biodiesel derived from recycled vegetable oil (RV) [5] are shown in table 1.

Table 1. Properties of CME compared with red diesel and biodiesel produced from recycled vegetable oil [5].

2.0 Experimental Equipment and Tests:

The Engine used for the tests was a Perkins D3.152 engine, the main features of which are presented in the table 2 and displayed in figure 2 . The air consumption of the engine was measured using the air box method and the cylinder pressure was sensed by a Kistler Piezo pressure transducer (type 401). The transducer was calibrated against a dead weight tester prior to the test. The engine was coupled to a hydraulic dynamometer through a BHL torque transducer. Load was applied to the engine by adjusting a control valve that set the delivery pressure of the dynamometer. The torque and speed of the engine were measured and from these the engine output power determined. Thermocouples (type $\mathrm{K}$ fast response) were used to take various temperature measurements on the test bed. The overall air fuel ratio was calculated by the Horiba analyser. Following the method adopted by Pramanik [6] and Puhan etal [7] the test fuel was blended at different levels with conventional base diesel fuel. The mixtures contained $5 \%, 10 \%, 20 \%$, and $50 \%$ CME (designated as B5, B10, B20 and B50) on a volume basis and tests were also performed with $100 \% \mathrm{CME}$ and $100 \%$ red diesel (designated B100 and D100 respectively). Fuel flow measurements were made using an ISO-certified graduated cylinder connected to the fuel inlet piping via a three-way valve. A second three-way valve allowed fuel to be diverted from the fuel return line to the graduated cylinder thus forming a closed loop and ensuring that only the fuel consumed by the engine was measured. At each engine setting the time to consume a measured quantity of fuel was recorded. The exhaust flue gas concentrations of $\mathrm{CO}, \mathrm{HC}, \mathrm{CO}_{2}, \mathrm{O}_{2}$ and $\mathrm{NO}_{\mathrm{x}}$ were measured with an Horiba PG-250 analyse which was calibrated at the start and the end of

Table 2 Data of the Perkins Engine

Figure 2 Test bed layout

each days testing with span gases and the drift determined. The drift is a result of two factors, zero drift due to a change in ambient conditions and span drift produced by a change in the sensitivity of the instrument. The drift per hour was determined from the initial and final calibration and used to correct the experimental readings. The zero calibration was established using Nitrogen as a zero gas and the composition of the span gases is shown in table 3 .

Table 3 Span gas concentrations

The systematic uncertainty of the analyser is $\pm 0.5 \%, \pm 2 \%$ and $\pm 1 \%$ in terms of 
repeatability, linearity and drift. The expected level of random uncertainties is shown in table 4. The smoke level was measured using a Bosch RTT100 smoke meter.

Table 4 random uncertainties of gas emission measurements

3.0 Engine Test Procedure:

The test performed was in conformity to ISO 8178-4, type E5 for diesel powered marine craft of less than $24 \mathrm{~m}$ in length. The test load points for this test are shown in table 5. The weighting factor is used to calculate specific exhaust emissions. The engine was warmed up at a light load setting with $100 \%$ diesel fuel until thermal stability was established in conformity with the manufacturer's recommendations. The test fuel was then delivered to the engine which was allowed to run for several minutes to clear the common parts of the fuel system of the pure diesel fuel. The load on the engine was then set at the test condition by adjusting the control valve on the dynamometer and at the same time the fuelling was adjusted to bring the engine to the test speed. The exhaust gas temperature; inlet water temperature; outlet water temperature and water jacket temperature were measured and monitored throughout the test. The fuel consumption was measured once the engine was stabilised at the operating point. Throughout the test the ambient air temperature and humidity readings were recorded to facilitate $\mathrm{NO}_{\mathrm{x}}$ correction in accordance to ISO 8178-1 to normalise the test readings to standard ISO conditions with humidity of $10.71 \mathrm{~g} / \mathrm{kg}$ and ambient temperature of $25^{\circ} \mathrm{C}$.

Table 5 Test mode cycle ISO 8178-4 type 5

4.0 Test Results and Discussions:

The brake thermal efficiency of the engine with diesel fuel and the various blends of CME with red diesel (B5, B20, B50 and B100) was determined from the measured results and plotted against brake power output as shown in figure 3. The test results show that with increasing brake power the thermal efficiencies of all the fuels show similar trends with the straight diesel fuel showing the better performance over the whole power/speed range. The $100 \% \mathrm{CME}$ showed the worst performance. The drop in thermal efficiency with increase in the blend of CME-bio-diesel can be attributed to the higher fuel supply for a given power which produces slower combustion times and counteracts the possible benefit of the presence of fuel borne oxygen in enhancing the combustion process. The combustion chamber and injection characteristics of the test engine were optimised for operation with red diesel so it is possible that small modifications to the injection timing may improve the situation for the bio-fuel. The calorific value of CME oil is 40.280 $\mathrm{MJ} / \mathrm{kg}$ as compared to the $42 \mathrm{MJ} / \mathrm{kg}$ for the diesel fuel. These results are in general agreement with those of Pramanik [6] and Puhan et al [7, 8] for other bio-fuel diesel blends. 
Figure 3 Brake thermal efficiency (\%) vs. engine power for the test fuels

The brake specific fuel consumption (bsfc) of the CME varies depending on the engine power and speed. For all the fuels tested the consumption was high at low speed but decreased with increasing speed. This is shown in figure 4.

Figure 4. Brake specific fuel consumption vs. engine speed (rpm) for the test fuels.

At high speeds, friction heat losses and deteriorating combustion increases bsfc. Although the blend gave almost the same power as red diesel, its bsfc is higher. This can be attributed to the oxygen content of the CME which takes no part in the combustion process and reduces the heating value compared with red diesel fuel. With an increase in biodiesel percentage in the blends, the calorific value of the mixture decreases. Hence the specific fuel consumption of the higher percentage of biodiesel in blends also increases. It can be concluded that the amount of fuel required to produce the same amount of power output varies from oil type and the loading conditions. Raheman and Gadge [9] reported that higher densities resulted in higher values for bsfc. As the density of B100 was higher than that of diesel fuel, it means the same fuel consumption on a volume basis resulted in higher bsfc as the proportion of CME is increased. The variation of exhaust temperature with bmep is shown in figure 5. The highest exhaust gas temperature of $448^{\circ} \mathrm{C}$ was recorded for the $\mathrm{B} 100$ at the maximum power of $30 \mathrm{~kW}$. The least exhaust temperature of $165^{\circ} \mathrm{C}$ was with $\mathrm{D} 100$ at $7.5 \mathrm{~kW}$ power rating. There is a steady rise of temperature as the power and speed are increased on the engine. The B5, B20 and B50 have almost a similar rating of exhaust heat. The poorer combustion characteristic of the CME as a result of its higher viscosity compared to the red diesel was assumed to be the cause. The higher exhaust temperature of the Croton SME is indicative of lower thermal efficiency, less of the energy input in the fuel was converted to useful work, and the remaining heat is given out as exhaust temperature [6]. Puhan [8] considered that the high exhaust temperature results from longer ignition delays that produce a higher exhaust temperature but AlWidyan et al, [10] stated that the higher exhaust temperatures may result from higher combustion temperatures.

Figure 5 Exhaust Temperature vs bmep for the test fuels.

The emissions of Carbon Monoxide (CO) from the test engine when fuelled with the diesel and the CME and its blends are compared in figure 6. The $\mathrm{CO}$ emissions of the blends were higher than those of the Diesel fuel at the higher load and speed settings but were lowest at the lower speed and power settings.

The increase of the CME percentage in the fuel blend reduces the $\mathrm{CO}$ at the low load setting as the B100 has the least CO but the reverse is the case with the higher load settings. There are several variables acting on the combustion process that has an impact on $\mathrm{CO}$ formation. The additional Oxygen present in the CME will assists in making the 
combustion more complete in the combustion zone but at the high load condition the increased viscosity of the CME could affect the fuel injection and atomisation characteristics could adversely impact on the CME as the injector was optimised for Diesel fuel. The increased in-cylinder temperatures at high load would have a greater impact on the $\mathrm{CO}$ production of Diesel fuel due to the enhanced atomisation and mixing this produces. Modifications to the fuel injection system may improve the atomisation characteristics of the CME and hence improve the combustion at high load. 
Figure 6 Variation of $\mathrm{CO}$ emissions with speed and load for CME and its blend with red diesel

Figure 7 shows the differences in $\mathrm{HC}$ emission between the blends of the biodiesel and the red diesel. The recorded emission levels for the biofuel are comparatively low and reduce with increased engine speed until at $2200 \mathrm{rpm}$ they increased. This has been observed for other biofuels [10] for reasons related to the oxygen content of the fuel. Studies by Monyem etal [11] show that unburned hydrocarbons generally emanate from the regions in a cylinder where there is a poor fuel/air mixture to such a high extent that the ratio is past the combustion limit. This process would be less likely to occur with fuel borne oxygen that can extend the combustion limit and reduce the extent of fuel quench. The B20 has shown a consistent low level of HC emission in this study compared to both the B100 and D100 at $1380 \mathrm{rpm}$ and $1760 \mathrm{rpm}$ but slightly higher than the diesel at 2002 and $2200 \mathrm{rpm}$. Without information about the complex in-cylinder combustion chemistry further considerations on this matter are just speculation but the results are encouraging.

Figure 7 Variation of $\mathrm{HC}$ emissions with speed for $\mathrm{CME}$ and its blends with red diesel

There was a general increase of NOx emissions as load and speed were increased. This increase in $\mathrm{NOx}$ is consistent with increase in cylinder temperature and exhaust temperature but the emissions for the bio-fuel were lower than the red diesel fuel at higher operating loads as shown in figure 8 . These results are in agreement of those found by Roskilly et al [5]. At low loads the overall oxygen concentration is higher but the combustion temperature is lower and (a feature of the chosen test method) the combustion time is longer which could both lead to low NOx but the fuel borne oxygen is most effective at producing NOx in the reaction zone which aided by the high local temperatures will then have more time to revert back to an equilibrium concentration [12].

Figure 8 Variation of NOx emissions with speed and load for CME and its blends with red diesel.

It has been observed from the result that at low load and speed the smoke emission is best with the red diesel fuel as a result of perhaps more favourable viscosity and density of this fuel as shown in figure 9. As the engine load and speed is increased, the smoke produced by the CME is initially higher than the red diesel for all blends but as the load is increased the bio-fuel begins to have a reduced level of emissions compared with the red diesel. The smoke emission of the Perkins engines for B100 is $20 \%$ less than that of red diesel, at high speed and load, but at the low speed and load that of the red diesel is the 
lowest. As more load was added, the temperature of the engine rises and makes combustion better for the CME. This is in agreement with the results of Mittlebach et al [13] who noticed that smoke density for biodiesel blend was generally lower than that of the diesel oil and they reasoned that higher thermal efficiency indicates better and complete combustion of fuel. Biodiesel has greater oxygen content than red diesel which may assist in reducing the smoke by locally increasing the constituent of oxygen available for combustion. Puhan et al [8] reported a reduction of $70 \%$ smoke in case of Mahua oil methyl ester when compared to diesel. The fuel injection equipment and timing of the test engine were at the normal setting for red diesel fuel; it may be that the smoke level for the CME could be lowered at low load if the injection timing was optimised for this fuel.

Figure 9 Variation of Smoke emissions with speed and load for CME and its blends with red diesel.

Carbon dioxide, $\left(\mathrm{CO}_{2}\right)$ has a great effect on the green house gases, in that it has the tendency to form a blanket effect on the atmosphere which aids global warming. The $\mathrm{CO}_{2}$ generated with the CME at the various loads and speed is shown in figure 10. There is a steady increase of $\mathrm{CO}_{2}$ with engine speed and load due to increased fuelling. The $\mathrm{CO}_{2}$ from Croton is seen to be higher than that of diesel fuel (D100). This is consistent with the lower hydrogen/carbon ratio and lower calorific value of the bio fuel. The $\mathrm{CO}_{2}$ emissions of the bio-fuel can however be considered as zero carbon emissions as they are sourced by the plant from air bourn carbon.

Figure 10 Variation of $\mathrm{CO}_{2}$ emissions with speed and load for $\mathrm{CME}$ and its blends with red diesel

The oxygen concentrations in the exhaust are shown in figure 11. The biofuel contains oxygen as part of its chemical make up which is not the case for red diesel fuel. It is expected that the oxygen content in the exhaust decreases as the engine load is increased as the air fuel ratio decreases with load.

Figure 11 Variation of exhaust $\mathrm{O}_{2}$ content with speed and load for CME and its blends with red diesel

5. Conclusions and Recommendations:

This paper has demonstrated that biodiesel from Croton Megalocarpus has a very strong potential for use as a biofuel for diesel engines in terms of power output, economy and exhaust emissions. The performance of a Perkins engine when fuelled with biofuel and 
biofuel/diesel blends is very similar to that when fuelled with red diesel. The main conclusions derived from this research are;

- The Croton biodiesel when blended with diesel fuel produces a level of performance in economy and exhaust emissions that are very similar to other biofuels from other sources.

- The brake thermal efficiency of the engine when fuelled with pure CME and the blended fuels is lower than that of red diesel fuel for the particular engine tested.

- The fuel consumption of B5, B20, B50 and B100 at $1380 \mathrm{rpm}$ and $7.5 \mathrm{~kW}$ power was $404.03,415.5,420,424 \mathrm{~g} / \mathrm{kWhr}$ respectively. This represented an increase of $2.65 \%$, $3.8 \%, 4.7 \%$ and $4.7 \%$ respectively over that of basic red diesel fuel.

- $\mathrm{CO}, \mathrm{CO}_{2}$ and $\mathrm{HC}$ emissions were higher for the CME and blends but the smoke emission were lower when compared to the red diesel fuel.

- The experimental results tentatively support the assertion that methyl esters of Croton Megalocarpus can be successfully used in existing diesel engines without modifications but this needs to be verified by further long term and comprehensive tests. Use of the bio-diesel as a partial fuel substitute can stimulate the rural farm economy in Africa, bring unproductive land back into profitable production, slow desert encroachment and make farming communities self reliant.

\section{References:}

1) David, P. and Patzek T.W. "Ethanol production using corn, switchgrass, and wood; biodiesel production using soybean and sunflower." Natural Resource Research 14(1): (2005) 65-76.

2) Chudnoff, M. "Tropical timbers of the world". USDA Forest Services (1984).

3) Dale, I. R. and P. J. Greenway "Kenya trees and shrubs", Buchanan Estates, Nairobi. (1984).

4) Beentje, H. J. "Kenya trees, shrubs and lianas". (1994).

5) Roskilly, AP. Nanda SK. Wang YD. Chirkowski J. "The performance and the gaseous emissions of two small marine craft diesel engines fuelled with biodiesel". Applied Thermal engineering, 28 (2008), 872-880.

6) Pramanik, K. "Properties and use of jatropha curcas oil and diesel fuel blends in compression ignition engine." Renewable Energy 28(2): (2003). 239-248.

7) Puhan, S. Vedaraman N. "Mahua oil (Madhuca Indica seed oil) methyl ester as biodiesel-preparation and emission characterstics." Biomass and Bioenergy 28(1): (2005) 87-93.

8) Puhan, S. Vedaraman N. "Performance and emission study of Mahua oil (madhuca indica oil) ethyl ester in a 4-stroke natural aspirated direct injection diesel engine." Renewable Energy 30(8): (2005) 1269-1278.

9) Raheman, H. And Ghadge S.V. "Performance of compression ignition engine with mahua (Madhuca indica) biodiesel." Fuel 86 (16): (2007) 2568-2573.

10) Al-Widyan, M. Tashtoush G. Abu-Qudais M. "Utilization of ethyl ester of waste vegetable oils as fuel in diesel engines." Fuel Processing Technology 76(2): (2002) 91-103.

11) Monyem, A. and Van Gerpen J. H. "The effect of biodiesel oxidation on engine performance and emissions." Biomass and Bioenergy 20(4): (2001) 317-325. 
12) Usta. N, Ozturk E. Can B. Conkur E.S. Nas S. Con A.H. Can A.C. and Topcu M., "Combustion of biodiesel fuel produced from hazelnut soapstock/waste sunflower oil mixture in a Diesel engine".Energy Conversion and Management (46 (2005) 741-755.

13) Mittelbach, M. and Remschmidt C. "Biodiesel: The comprehensive handbook". Austria, Martin Mittelbach 2006. 
Table 1

\begin{tabular}{|c|c|c|c|c|c|c|c|c|}
\hline Property & Units & $\begin{array}{l}\text { B100 } \\
100 \% \\
\text { CME }\end{array}$ & $\mathrm{RVO}$ & $\begin{array}{l}\text { D100 } \\
100 \% \\
\text { Diesel }\end{array}$ & $\begin{array}{l}\text { B5 } \\
5 \% \\
\text { CME } \\
95 \% \\
\text { Diesel }\end{array}$ & $\begin{array}{l}\text { B10 } \\
10 \% \\
\text { CME } \\
90 \% \\
\text { Diesel }\end{array}$ & $\begin{array}{l}\text { B20 } \\
20 \% \\
\text { CME } \\
80 \% \\
\text { Diesel }\end{array}$ & $\begin{array}{l}\text { B50 } \\
50 \% \\
\text { CME } \\
50 \% \\
\text { Diesel }\end{array}$ \\
\hline $\begin{array}{l}\text { Gross } \\
\text { calorific } \\
\text { value } \\
(\mathrm{GCV})\end{array}$ & $\mathrm{MJ} / \mathrm{kg}$ & 40.28 & 39.66 & 45 & 44.75 & 44.5 & 44. & 43.15 \\
\hline $\begin{array}{l}\text { Ignition } \\
\text { delay }\end{array}$ & $\mathrm{ms}$ & 4.1 & & & & & & \\
\hline $\begin{array}{l}\text { main } \\
\text { combustion } \\
\text { delay }\end{array}$ & $\mathrm{ms}$ & 3.46 & & & 7 & & & \\
\hline $\begin{array}{l}\text { Cetane } \\
\text { number }\end{array}$ & & 40 & & $42-45$ & & & & \\
\hline $\begin{array}{l}\text { Carbon } \\
\text { content }\end{array}$ & $\begin{array}{l}\% \\
\text { Volume }\end{array}$ & 77.83 & 76.76 & 86.19 & 85.77 & 85.34 & 84.5 & 82.0 \\
\hline $\begin{array}{l}\text { Hydrogen } \\
\text { content }\end{array}$ & $\begin{array}{l}\% \\
\text { Volume }\end{array}$ & 11.97 & 11.97 & 12.62 & 12.58 & 12.55 & 12.49 & 12.29 \\
\hline $\begin{array}{l}\text { Oxygen } \\
\text { content }\end{array}$ & $\begin{array}{l}\% \\
\text { Volume }\end{array}$ & 10.2 & 10.7 & 0.1 & 0.605 & 1.11 & 2.12 & 5.2 \\
\hline $\begin{array}{l}\text { Sulphur } \\
\text { content }\end{array}$ & $\begin{array}{l}\% \\
\text { Volume }\end{array}$ & 0.0017 & $<0.001$ & 0.13 & 0.123 & 0.117 & 0.104 & 0.065 \\
\hline Ash content & $\begin{array}{l}\% \\
\text { Volume }\end{array}$ & $<0.01$ & $<0.01$ & $<0.01$ & $<0.01$ & $<0.01$ & $<0.01$ & $<0.01$ \\
\hline $\begin{array}{l}\text { Density at } \\
15^{\circ} \mathrm{C}\end{array}$ & $\mathrm{kg} / \mathrm{m}^{3}$ & 904.4 & 884.1 & 860.8 & 862.2 & 864.4 & 868.6 & 870.2 \\
\hline $\begin{array}{l}\text { Viscosity at } \\
40^{\circ} \mathrm{C} \\
\end{array}$ & $\mathrm{mm}^{2} / \mathrm{s}$ & 4.8 & & $2-4.5$ & & & & \\
\hline & & & & & & & & \\
\hline
\end{tabular}


Table 2

\begin{tabular}{|l|l|l|}
\hline Parameter & Description & Remarks \\
\hline Type & D3.152 & $\begin{array}{l}\text { Three Cylinder, four } \\
\text { stroke direct injection }\end{array}$ \\
\hline Bore & $91.44 \mathrm{~mm}$ & $3.6 \mathrm{in}$ \\
\hline Stroke & $127 \mathrm{~mm}$ & $5 \mathrm{in}$ \\
\hline Swept volume & 2.5 I & $152 \mathrm{cu}$ in \\
\hline Rated speed & $2200 \mathrm{rpm}$ & $45 \mathrm{HP}$ at $2500 \mathrm{rpm}$ \\
\hline Rated power & $33.56 \mathrm{~kW}$ & \\
\hline Idling speed & $500 \mathrm{rpm}$ & \\
\hline Firing order & $1,2,3$ & \\
\hline Compression ratio & $18.5: 1$ & \\
\hline
\end{tabular}


Table 3

\begin{tabular}{|l|l|}
\hline Span gas & Concentration \\
\hline $\mathrm{CO}$ & \\
\hline $\mathrm{CO}_{2}$ & $1390 \mathrm{ppm}$ \\
\hline $\mathrm{NOx}$ & $13.9 \%$ \\
\hline $\mathrm{O}_{2}$ & $1390 \mathrm{ppm}$ \\
\hline
\end{tabular}


Table 4

\begin{tabular}{|l|l|l|l|l|}
\hline & $\mathrm{CO}(\mathrm{ppm})$ & $\mathrm{CO}_{2}(\%)$ & $\mathrm{NO}_{\mathrm{x}}(\mathrm{ppm})$ & $\mathrm{O}_{2}(\%)$ \\
\hline Initial span & 1385 & 13.91 & 1388 & 21.2 \\
\hline Maximum span drift & 63 & 0.34 & 87 & 0 \\
\hline Maximum zero drift & 1 & 0 & 0 & 0.16 \\
\hline Full scale of analyser & 2000 & 20 & 2500 & 100 \\
\hline Span drift on full scale (\%) & 3.15 & 1.7 & 3.48 & 0 \\
\hline Zero drift on full scale (\%) & 0.05 & 0 & 0 & 0.16 \\
\hline
\end{tabular}


Table 5

\begin{tabular}{|l|l|l|l|l|l|}
\hline Mode number (Cycle E5) & Mode 1 & Mode 2 & Mode 3 & Mode 4 & Mode 5 \\
\hline Speed \% of Max & 100 & 91 & 80 & 63 & Idle \\
\hline Power \% of Max & 100 & 75 & 50 & 25 & 0 \\
\hline Engine speed rpm & 2200 & 2002 & 1760 & 1380 & 500 \\
\hline Engine power kW & 33.56 & 25.17 & 16.78 & 8.39 & - \\
\hline Engine Torque Nm & 145 & 119 & 90.9 & 58.8 & - \\
\hline Weighting Factor & 0.08 & 0.13 & 0.17 & 0.32 & 0.3 \\
\hline
\end{tabular}




\section{Caption to figures}

Figure 1 A Croton Megalocarpus tree grown as an ornamental plant in Kenya

Figure 2 Test bed layout

Figure 3 Brake thermal efficiency (\%) vs. engine power for the test fuels

Figure 4 Brake specific fuel consumption vs. engine speed (rpm) for the test fuels.

Figure 5 Exhaust Temperature vs bmep for the test fuels

Figure 6 Variation of $\mathrm{CO}$ emissions with speed and load for CME and its blend with red diesel

Figure 7 Variation of $\mathrm{HC}$ emissions with speed for $\mathrm{CME}$ and its blends with red diesel

Figure 8 Variation of NOx emissions with speed and load for CME and its blends with red diesel

Figure 9 Variation of Smoke emissions with speed and load for CME and its blends with red diesel.

Figure 10 Variation of $\mathrm{CO}_{2}$ emissions with speed and load for $\mathrm{CME}$ and its blends with red diesel

Figure 11 Variation of exhaust $\mathrm{O}_{2}$ content with speed and load for CME and its blends with red diesel 


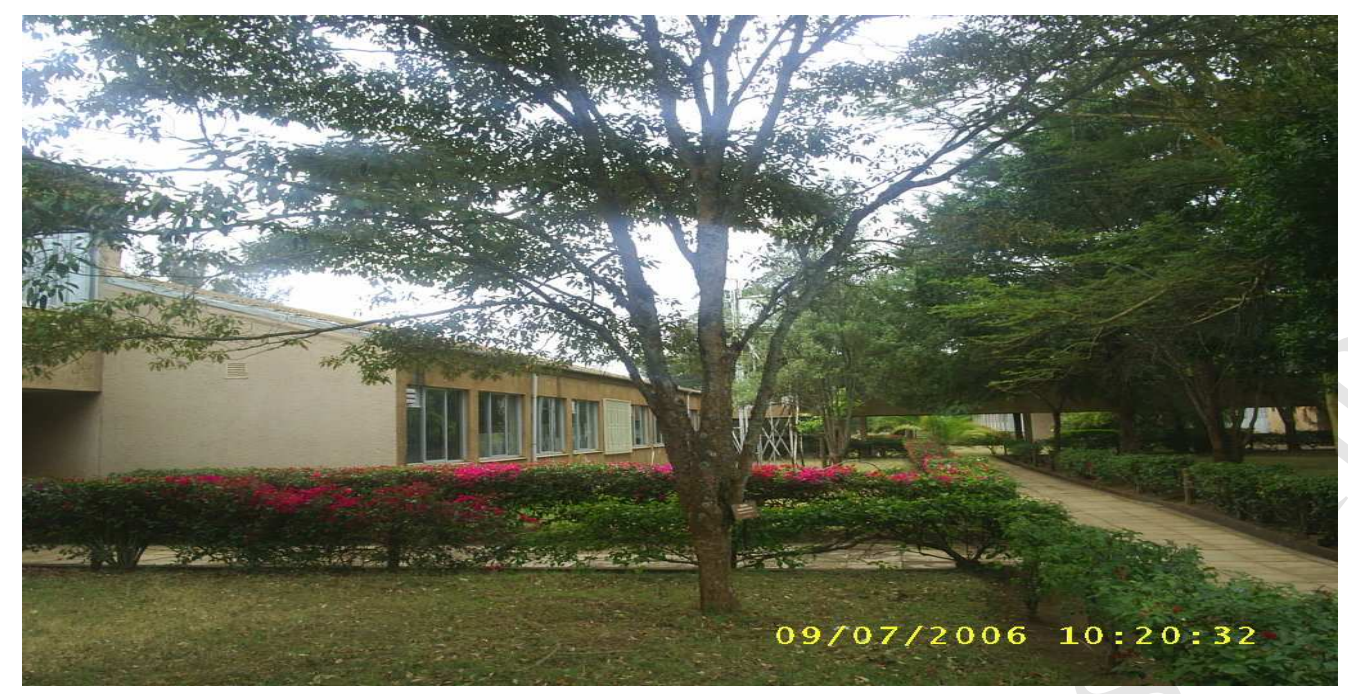

Figure 1 
Figure 2 Test bed layout.

1. Engine

2. Torque meter

3. Hydraulic dynamometer

4. Hydraulic oil tank

5. Hydraulic oil cooler

6. Engine coolant cooler

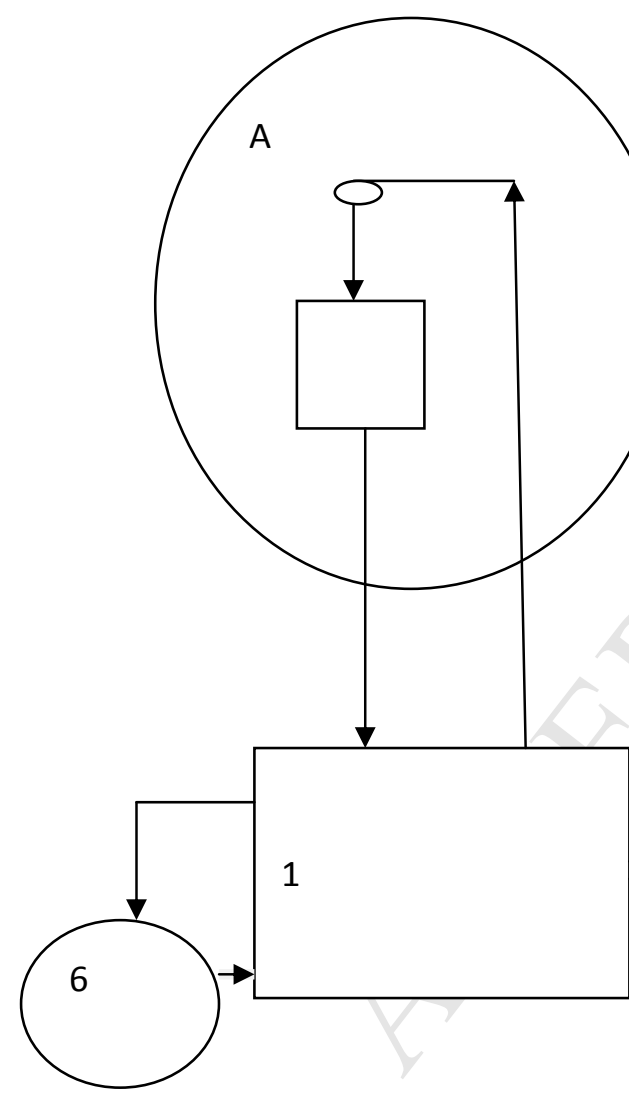

Detail A engine fuel supply arranged to draw fuel from the tank.

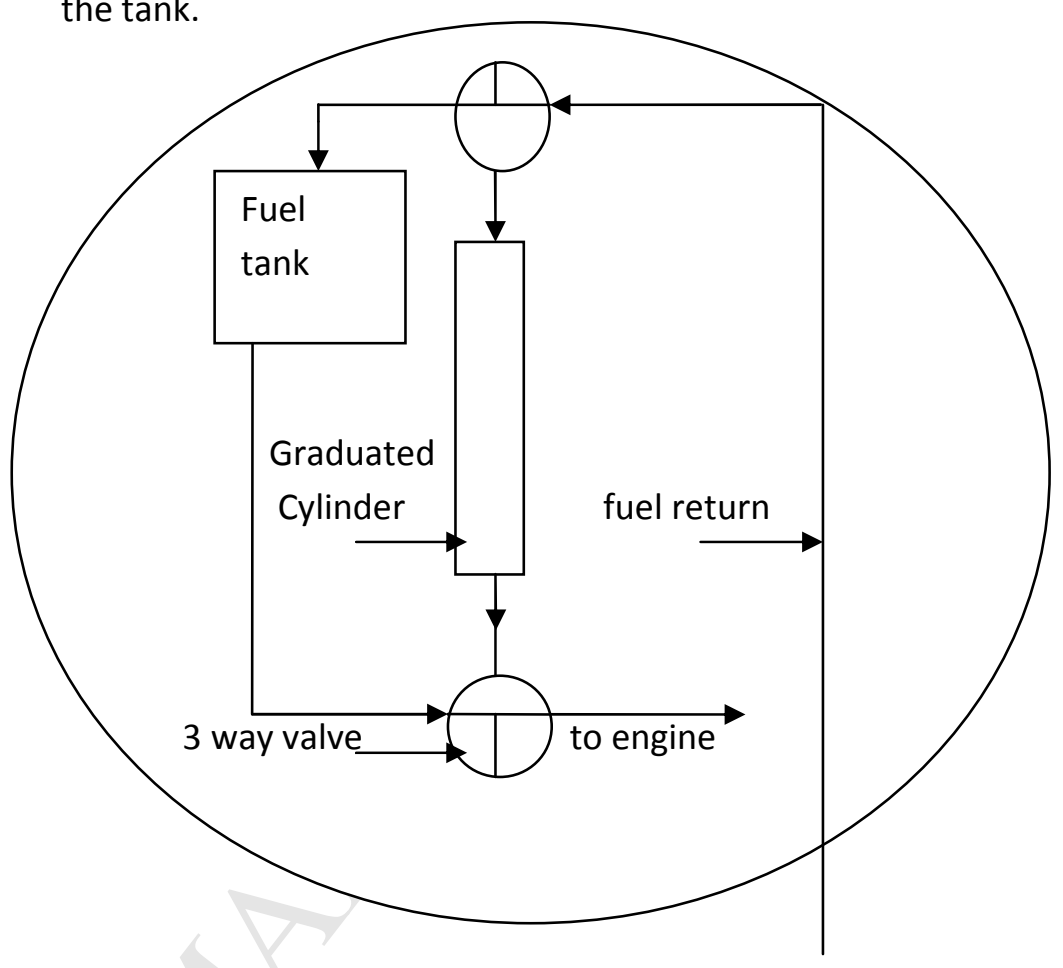




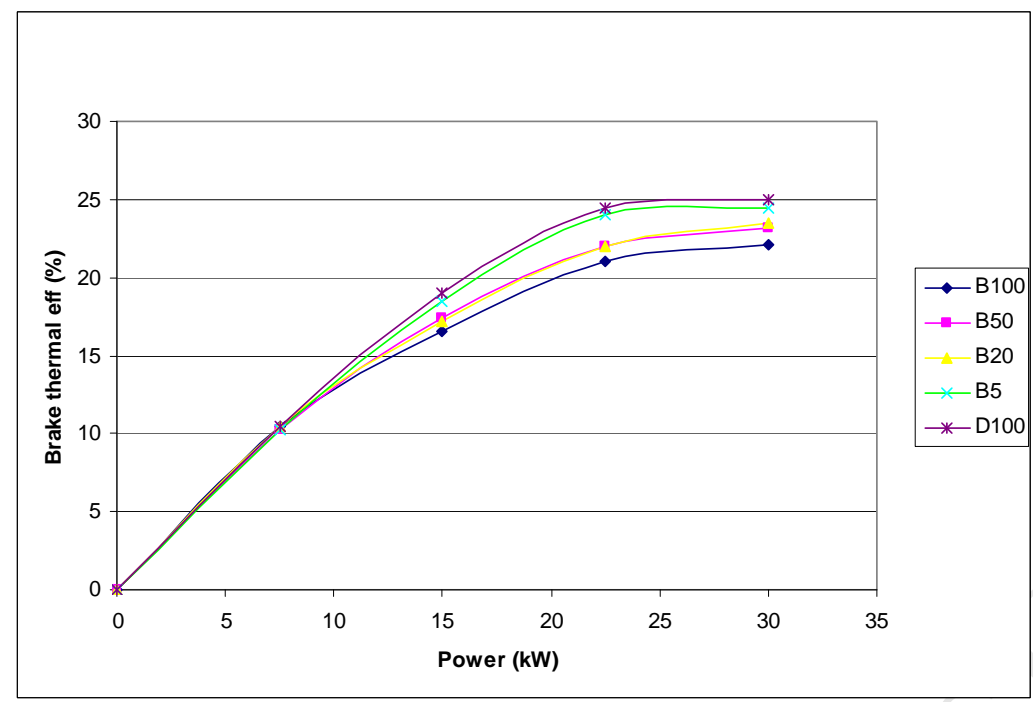

Figure 3 


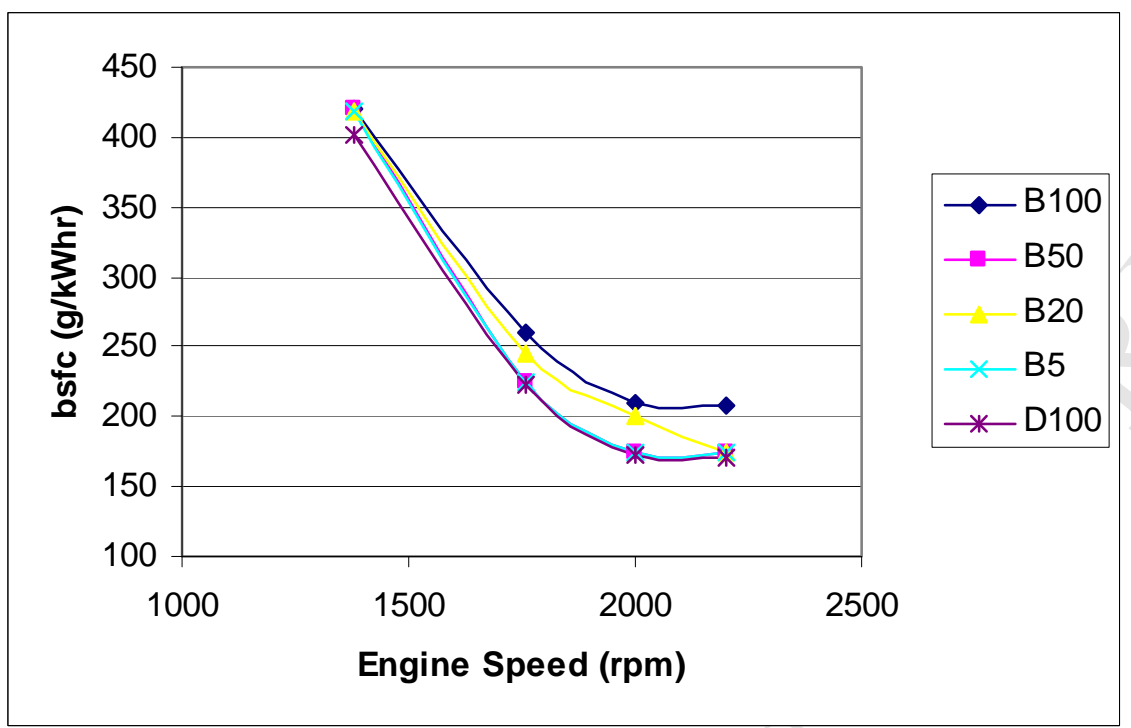

Figure 4 


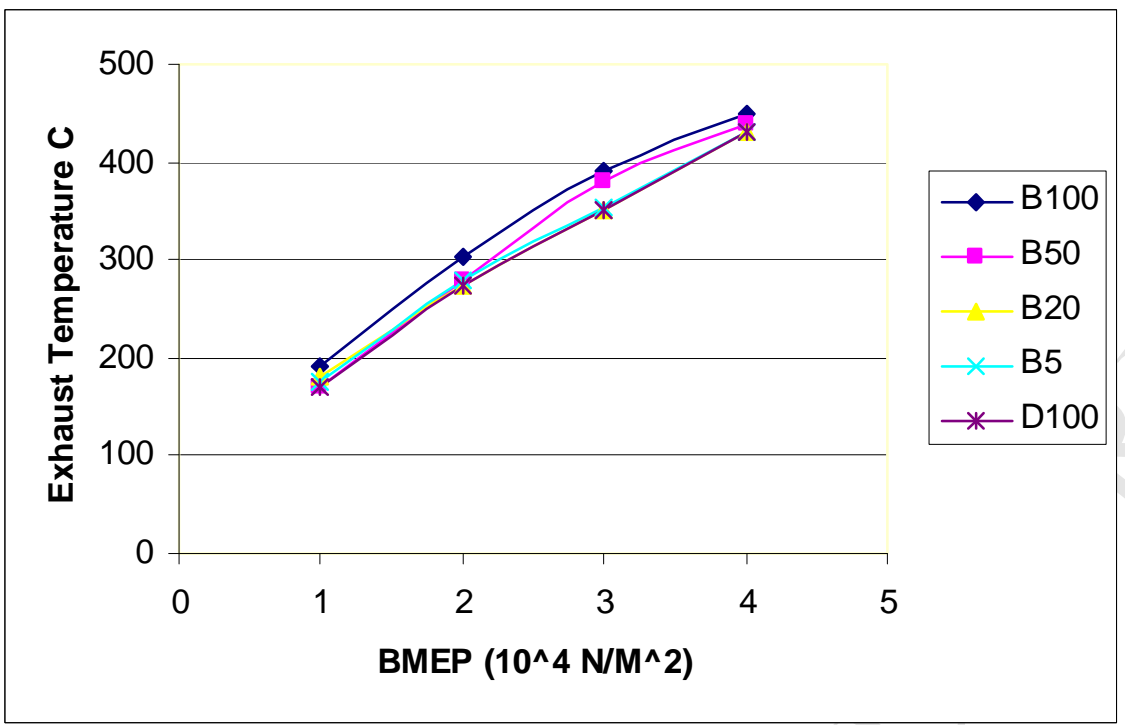

Figure 5 


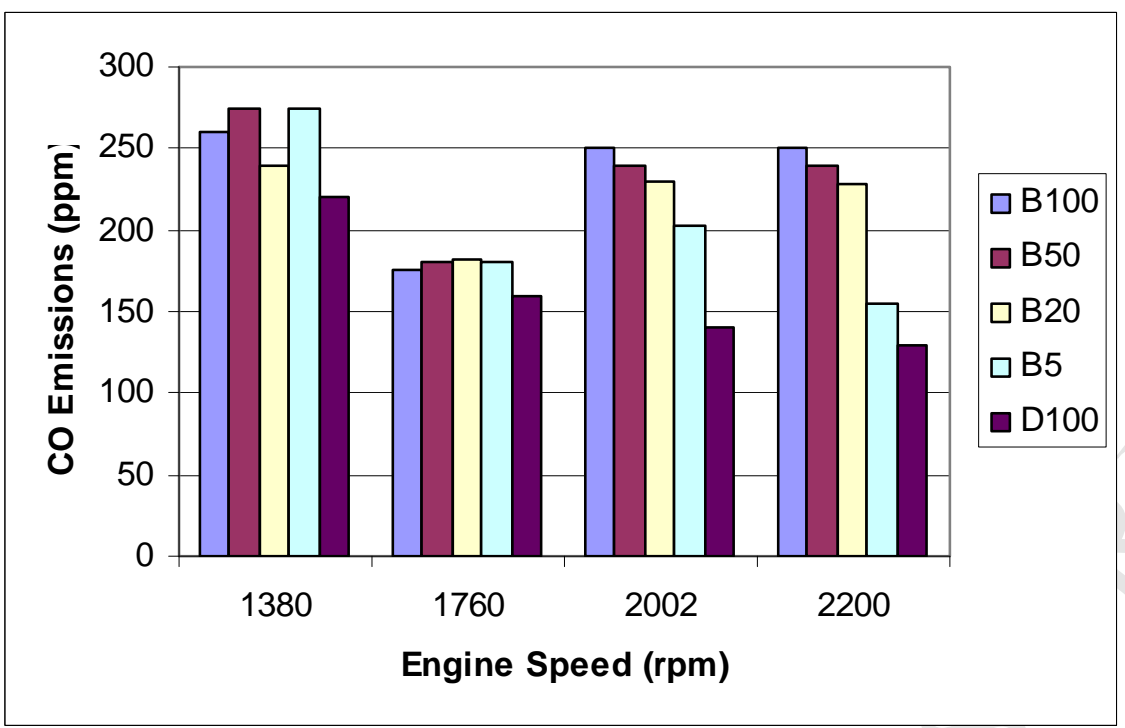

Figure 6 


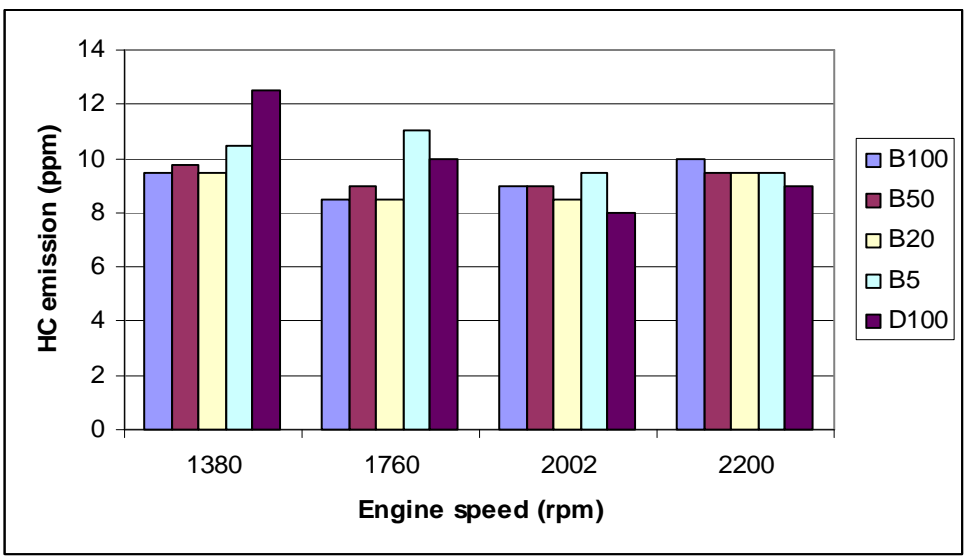

Figure 7 


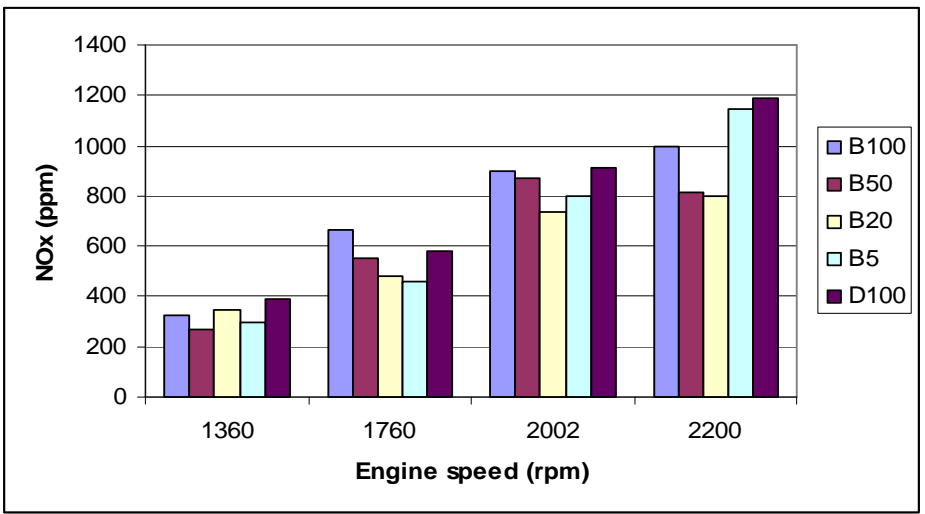

Figure 8 


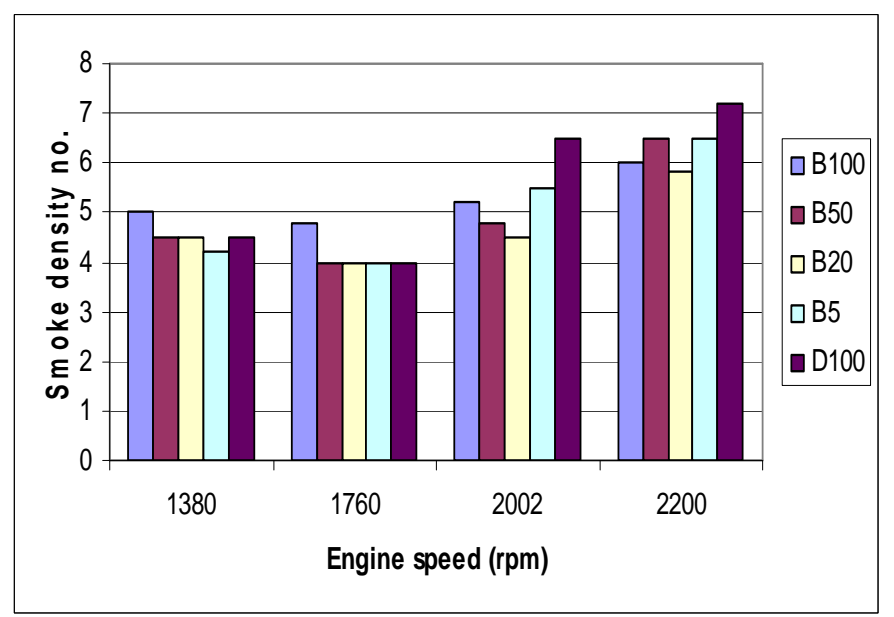

Figure 9 


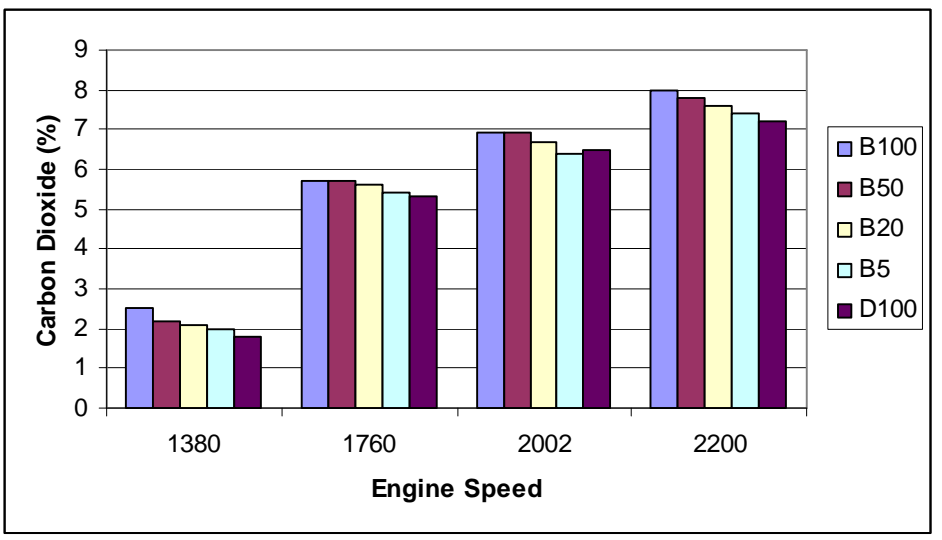

Figure 10 


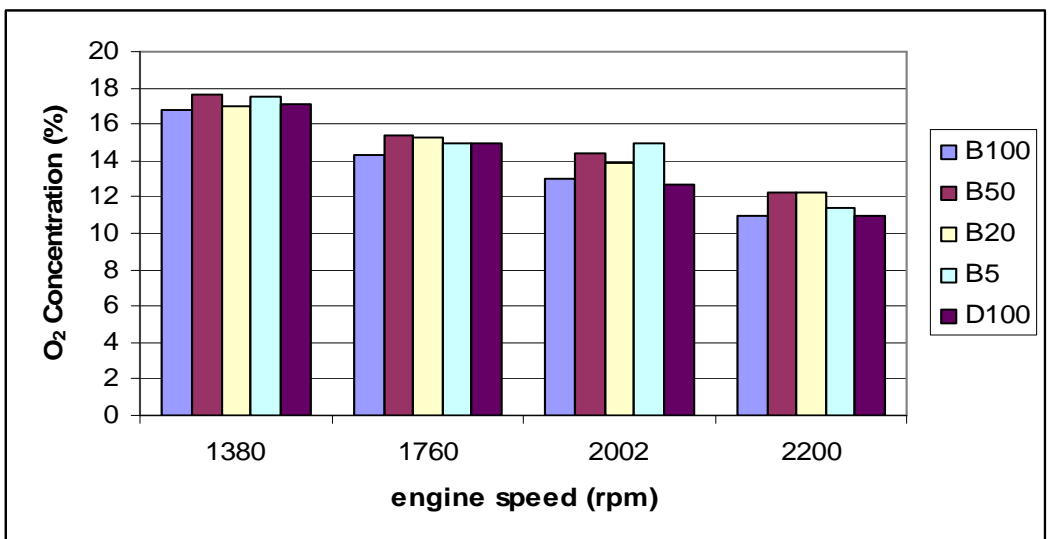

Figure 11 